JPE (Jurnal Pendidikan Edutama) Vol. 8 No. 2 Juli 2021

P-ISSN: 2339-2258 (Print) E-ISSN: 2548-821X (Online)

http://ejurnal.ikippgribojonegoro.ac.id/index.php/JPE

\title{
PENANAMAN PENDIDIKAN KARAKTER MELALUI PEMECAHAN MASALAH MATEMATIKA
}

\author{
Dwi Erna Novianti \\ FPMIPA, IKIP PGRI Bojonegoro \\ Email: Dwi.Erna@ikippgribojonegoro.ac.id
}

\begin{abstract}
The development of technology which is increasingly rapid nowadays certainly has a positive and negative impact on student development, especially on character development. The role of integration character education is very needed as an effort to overcome this. So far, character education is identical to the subject of Religion or Pancasila Education only. However, the development of time, the integratio of character education can be integrated with the entire learning process, including the learning process of mathematics. Teachers play an important role in this. Teachers can become facilitators and role models in providing role models in behavior, attitudes, and speech related to cultivating student character. Teachers can also develop and instill character education in the learning process from the planning stage to the evaluation stage. The use of models, strategies, and learning approaches can help teachers instill character values. One approach that can be used is to use mathematic problem solving which includes several steps to solve it, namely (1) understanding the problem, (2) planning for problem solving, (3) solving results and (4) checking the answer again. At each completion step contains character values that can be developed, including values of interest, hard work, independence, negotiation and persistence.
\end{abstract}

Keyword: Character Education, Mathematicl Problem Solving

\begin{abstract}
Abstrak
Perkembangan teknologi yang semakin pesat pada masa sekarang ini tentunya mempunyai dampak positif dan negatif terhadap perkembangan siswa terutama terhadap perkembangan karakter. Peran pengintegrasian pendidikan karakter sangat diperlukan sebagai salah satu upaya mengatasi hal tersebut. Selama ini, pendidikan karakter identik dengan mata pelajaran Agama atau Pendidikan Pancasila saja. Akan tetapi seiring perkembangan waktu, penanaman pendidikan karakter dapat diintegrasikan dengan seluruh proses pembelajaran tidak terkecuali proses pembelajaran matematika. Guru mempunyai peran penting dalam hal ini. Guru dapat menjadi fasilitator dan sebagai role model dalam memberikan tauladan dalam perilaku, sikap, dan ucapan terkkait penanaman karakter siswa. Guru juga dapat mengembangkan dan menannamkan pendidikan karakter dalam proses kegiatan pembelajaran mulai dari tahap perencenaan sampai dengan tahap evaluasi. Penggunaan model, startegi, dan pendekatan pembelajaran dapat membantu guru dalam menanamkan nilai - nilai karakter. Salah satu pendekatan yang dapat digunakan adalah dengan menggunakan pemecahan masalah matematika yang didalamnya memuat beberapa langkah penyelesaian yaitu (1) pemahaman masalah, (2) perencenaan penyelesaian masalah, (3) pelaksanaan rencana penyelesaian dan (4) mengecek kembali jawaban. Pada setiap langkah penyelesaian ini memuat nilai karakter yang dapat dikembangkan, diantaranya nilai ketertarikan minat, kerja keras, kemandirian, negoisasi dan kegigihan.
\end{abstract}

Kata kunci: Pendidikan Karakter, Pemecahan Masalah Matematika 


\section{PENDAHULUAN}

Bekembangnya teknologi yang semakin pesat dengan segala pengaruhnya terutama terhadap dunia pendidikan mempunyai dampak terhadap perkembangan karakter peserta didik. Karakter merupakan jati diri dan jati diri yang baik dapat dibentuk melalui pendidikan (Kesumawati, 2014). Hal tersebut sesuai dengan fungsi dari pendidikan nasional yang salah satunya adalah melalui pendidikan dapat membentuk watak dalam rangka mencerdaskan kehidupan bangsa.

Penananam pendidikan karakter sejak dini tentunya diperlukan seiring perkembangan jaman. Pendidikan karakter sebagai salah satu sarana penanaman nilai moral diharapkan mampu menjadi salah satu alternatif atau cara untuk menyeimbangkan antara perkembangan teknologi yang semakin pesat dengan segala pengaruhnya baik pengaruh positif maupun negatif. Pendidikan karakter mempunyai tujuan penanaman nilai dalam diri siswa dan pembaruan tata kehidupan bersama yang lebih menghargai kebebasan individu (Maunah, 2016). Untuk mewujudakan hal tersebut, guru mempunyai peran penting dalam memberikan tauladan bagi peserta didik secara langsung dengan menerapkan perilaku disiplin, tanggungjawab, jujur, dan mandiri dalam proses pembelajaran.

Sementara itu berkaitan dengan pembelajaran matematika yang selama ini sebagian besar mengarah pada kemampuan kognitif saja, pendidikan karakter dapat diwujudkan proses proses pembelajaran matematika yang dilakukan oleh guru atau dosen dengan mengintegraskan antara hard skill dan soft skill yang dimiliki peserta didik. Penintegrasian ini bertujuan agar terjadi keseimbangan antara kemampuan secara kognitif dan afektif. Hal ini sesuai dengan tujuan dari pembelajaran matematika yang salah satunya adalah membekali peseta didik dengan kemampuan berpikir logis, matematis dan kemampuan kerjasama. Learning mathematics is an ongoing process to obtain new concepts, ideas, and knowledge-based on previous experience so that it can help us to think critically, logically, accurately, effectively and efficiently (Novianti, 2019). Berdasarkan pernyataan tersebut dapat disimpulkan bahwa pembelajaran matematika merupakan proses untuk mempelajari konsep dan ide baru, dan pengetahuan yang berbasis pengalaman yang dapat membantu peserta didik berpikir kritis, logis, efektf dan efisien.

Pemecahan masalah matematika merupakan salah satu bagian dari kemampuan matematis yang harus dimiliki siswa dalam rangka penanman pendidikan karakter. Tujuan pemecahan masalah dalam matematika adalah untuk meningkatkan kesediaan siswa dalam memperbaiki kemampuan mereka saat memecahkan masalah, meningkatkan konsep diri siswa sehubungan dengan kemampuannya menyelesaikan masalah, membuat siswa sadar akan strategi pemecahan masalah, serta membuat siswa sadar bahwa banyak masalah dapat dipecahkan lebih dari satu cara (Novianti, 2017). Berdasarkan uraian tersebut, dapat disimpulkan bahwa melalui pembelajaran pemecahan masalah siswa diharapkan dapat menyelesaikan pemecahan masalah yang dihadapi dalam kehidupan sehari - hari. Lantas, bagaimana kaitannya dengan pendidikan karakter?

\section{METODOLOGI}

Metode yang digunakan dalam arikel ini adalah Systematic Literature Review (SLR), yang mana metode ini menghasilkan sebuah atau berbagai literartur akademik yang reliable dan akurat (Suriyah et al., 2020). Terkait pengumpulan data, metode yang digunakan adalah dengan pengumpulan data dari beberapa artikel Jurnal, Buku, prosiding dan artikel lain yang bisa kita akses melalui internet (google scholar) 


\section{HASIL DAN PEMBAHASAN}

\section{Pendidikan Karakter}

Pendidikan karakter selalu identik dengan pelajaran Pendidikan Pancasila atau Pendidikan Agama. Pendidikan karakter mempunyai makna sistem pendidikan yang menanamkan nilai - nilai watak dan karakter siswa melalui tindakan untuk melakukan nilai tersebut. (Omeri, 2015). Meskipun pada kenyataan di lapangan pendidikan karakter sebagian besar merupakan tanggungjawab guru Pendidikan Pancasila dan guru Pendidikan Agama, namun sebenarnya hal itu tidak dibenarkan. Penanaman pendidkan karakter merupakan tanggungjawab semua guru dengan memberikan tauladan untuk siswa.

Tujuan Pendidikan Pendidikan Karakter (Omeri, 2015) diantaranya adalah (1) mengembangkan potensi afektif peserta didik sebagai manusia dan Warga Negara yang memiliki nilai-nilai budaya dan karakter bangsa, (2) mengembangkan Kebiasaan dan perilaku peserta didik yang terpuji dan sejalan dengan nilai-nilai universal dan tradisi budaya dan karakter bangsa, (3) menanamkan jiwa kepemimpinan dan tanggung jawab peserta didik sebagai generasi penerus bangsa, (4) mengembangkan kemampuan pesrta didik menjadi manusia yang mandiri, kreatif, berwawasan kebangsaan dan (5) mengembangkan lingkungan kehidupan sekolah sebagai lingkungan belajar yang aman jujur, penuh kreativitas dan persahabatan, serta dengan rasa kebangsaan yang tinggi dan penuh kekuatan.

Penanaman pendidikan karakter dalam pembelajaran dapat diwujudkan dengan menanamkan nilai - nilai karakter pada setiap kegiatan yang dilakukan oleh guru mulai dari tahap perencanaan pembelajaran sampai pada tahap peaksanaan pembelajaran (Pertiwi \& Marsigit, 2017). Tahap perencanaan meliputi kegiatan guru dalam menyusun perangkat pemelajaran, sedangkan tahap pelaksanaan meliputi pelaksanaan pembelajaran sesuai dengan apa yang sudah direncanakan dan melakukan teknik penilaian yang dapat mengukur hasil dan proses pendidikan karakter dan hasil pembelajaran. Berikut adalah Gambar proses penanaman pendidikan karakter dalam pembelajaran.

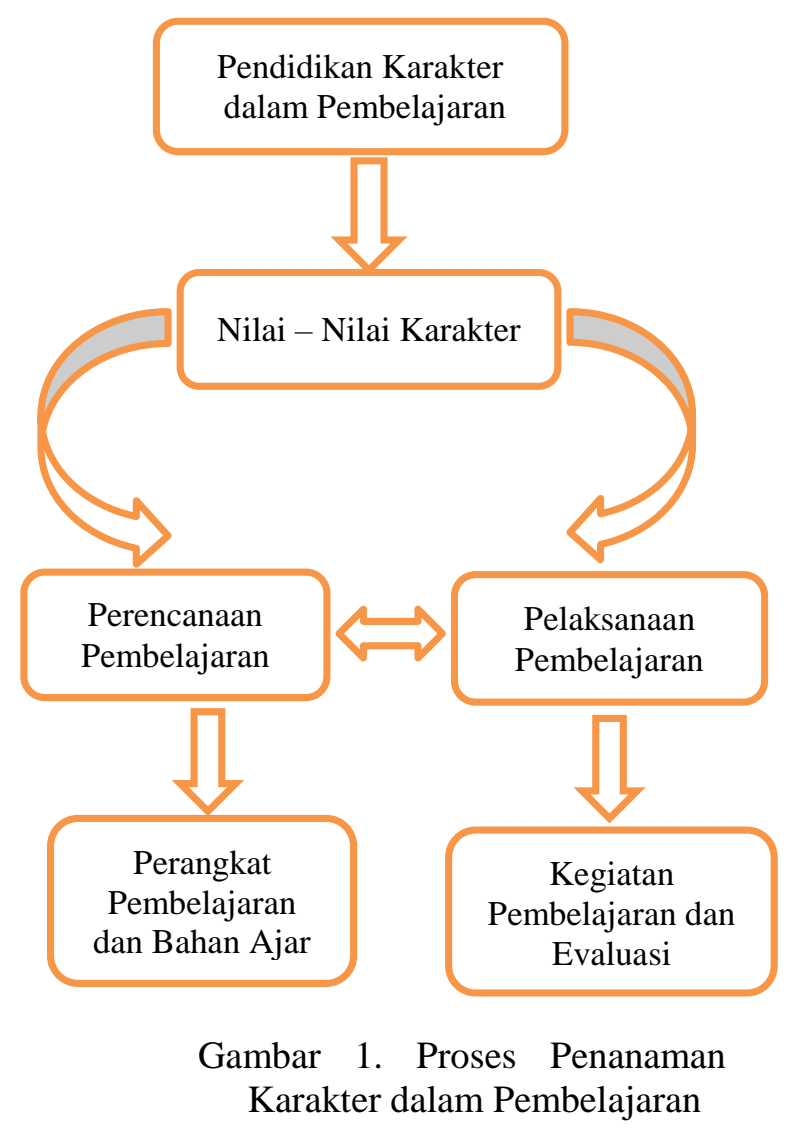

Standar yang menyatakan bahwa pendidikan merupakan cara efektif untuk mengembangkan karatkter adalah Character education quality $(C E Q)$. Menurut standar ini, pendidikan akan memberikan kontribusi efektif untuk mengembangkan karakter siswa melalui penanaman nilai - nilai dasar etika dan menjadikan nilai tersebut sebagai basis pendidikan (Maunah, 2016). Berdasarkan hal tersebut, maka pendidikan karakter mempunyai prinsip - prinsip antara lain: (1) menggunkan nilai - nilai etika sebagai basis karakter, (2) mengidentifikasi karakter secara komprehensif, (3) menggunakan pendekatan yang tepat untuk membangun karakter, (4) memfungsikan masyarakat dan lingkungan dalam pengembangan karakter, (5) menciptakan komunitas yang peduli terhadap perkembangan karakter siswa. 


\section{Pemecahan Masalah Matematika}

Proses pembelajaran matematika di sekolah mempunyai lima tujuan penting yaitu melatih kemampuan: (1) Pemecahan masalah, (2) pembuktian, (3) komunikasi, (4) koneksi, (5) representasi (Pambudi et al., 2020). Berdasarkan hal tersebut, menunjukkan bahwa kemampuan pemecahan masalah matematika adalah hal penting yang harus dimiliki siswa. Ada beberapa alasan mengapa pemecahan masalah ini penting bagi siswa (Liljedahl et al., 2016), diantaranya yaitu: (1) siswa diharuskan mengerti tentang permasalahan matematika, mengembangkan model dari permasalahan tersebut, dan mengurangi ketakutan mereka terhadap matematika, (2) siswa harus mengembangkan rasa dan antusisme dalam belajar matematika, (3) siswa akan lebih kritis dalam menganalisa permasalahan, (4) kemampuan pemecahan masalah adalah tujuan utama dari pembelajaran matematika dan merupakan objek utama dalam pembelajaran matematika.

Beberapa langkah diperlukan dalam proses pemecahan masalah matematika. Langkah - langkah pemecahan masalah matematika yang sering digunakan adalah dengan metode Polya. Polya membagi langkah - langkah tersebut dalam 4 tahap, yaitu (Polya, 1973): memahami masalah, membuat prencanaan penyelesaian masalah, melaksanakan rencana penyelesaian masalah, mengecek kembali hasil dari pemecahan masalah. (Tambunan, 2019) Penjelasan masing - masing tahap tersebut adalah (1) Memahami masalah. Indikator dalam memahami masalah adalah siswa dapat mengidentifikasi apa yang diketahui, ditanyakan dan apa yang diperlukan dalam penyelesaian masalah. (2) Membuat perencanaan. Indikator dalam tahap ini adalah siswa dapat memformulasikan permasalahan matematika dan membuat strategi dengan memodelkan permasalahan tersebut. (3) Melaksanakan rencana pemecahan masalah. Indikator tahap ini adalah menerapkan startegi pemodelan pemecahan masalah yang telah dibuat (4) Mengecek kembali hasil pemecahan masalah Indikator mengecek kembali permaslaahan adalah siswa dapat mejelaskan hasil yang diperoleh dengan cara mengaitkan dengan permasalahan awal.

Kemampuan pemecahan masalah siswa tidak dapat berkembang secara otomatis seperti halnya kemampuan berhitung (Wulandari \& Sukestiyarno, 2013). Kemampuan pemecahan masalah ini perlu diasah. Guru mempunyai peranan penting dalam hal ini. Guru dapat memberikan keterampilan pemecahan masalah melalui pembelajaran yang mencakup empat langkah peyelesaian seperti yang sudah dijelaskan di atas. Selain itu, melatih keterampilan kemampuan pemecahan masalah juga dapat diberikan dengan memberikan bamyak latihan soal pada setiap proses pembelajaran.

\section{Pendidikan Karakter dan Pemecahan Masalah}

Sejauh ini, ukuran keberhasilan seorang siswa masih dilihat dari kemampuan kognitifnya saja tanpa melihat kemampuan afektif dan psikomotornya. Nilai kognitif masih menjadi ukuran baku bagi siswa. Selayaknya pendidikan yang diselenggarakan harus membawa siswa ke pengenalan kehidupan nyata yang memuat penanaman pendidikan karakter didalamnya (Pertiwi \& Marsigit, 2017).

Pembelajaran matematika dapat dipandang sebagai suatu proses pembelajaran yang menanamkan nilai pendidikan karakter didalamnya. Hal ini sesuai dengan tujuan dari pembelajaran matematika yang termuat dalam Badan Standar Nasional Pendidikan (Pendidikan, 2006), yang diantarnaya adalah: (1) memahami konsep matematika, (2) menggunakan penalaran pada pola dan sifat, (3) memecahkan masalah, mengkomunikasikan gagasan dengan symbol (5) memiliki sikap menghargai kegunaan matematika dalam kehidupan. Berdasarkan tujuan - tujuan tersebut dapat terlihat jelas peran matematika dalam pembentukan pola pikir siswa yang berdampak terhadap karakter siswa.

Proses pembelajaran matematika dalam kaitannya dengan penananman pendidikan karakter dapat diaplikasikan dengan memaksimalkan fungsi guru di dalamnya. Guru mempunyai peran yang sangat penting yaitu sebagai fasilitator dan sebagai role model untuk siswa. Guru 
sebagai fasilitator mempunya peran untuk menanamkan konsep matematika secara optimal kepada siswa. Sedangkan guru sebagai role model mempunyai peran memberikan contoh perilaku yang bai kepada siswa serta menjadi mengontrol prilaku siswa agar sesuai dengan karakter yang diharapkan. Hal ini menunjukkan bahwa guru harus secara beriringan mampu mengajarkan konsep matematika sekaligus menanamkan pendidikan karakter didalamnya.

Proses penanaman konsep matematika dan pendidikan karakter yang beriringan tersebut data terwujud dengan menerapakan pendekatan pemecahan masalah matematika dalam proses pembelajarannya. Pendekatan dengan pemecahan masalah matematika menggunakan permasalahan yang identik dengan kehidupan sehari - hari. Pendekatan ini berbasis permasalahan yang harus diselesaikan melalui beberapa tahap penyelesaian, mulai dari perencanaaan sampai penentuan hasilnya. Proses dari tahap ke tahap tersebut memerlukan penalaran dan pemahaman konsep yang baik.

Sementara itu kaitannya dengan pendidikan karakter, penerapan pembelajaran dengan pemecahan masalah matematika dapat diwujudkan dalam proses berpikir dalam setiap langkah penyelesainnya. Contoh penanaman pendidikan karakter dalam pembelajaran dengan pendekatan pemecahan masalah matematika (Kesumawati, 2014). (1) Kegiatan Pendahuluan. Kegiatan pendahuluan berisi tentang penyampaian tujuan pembelajaran, menyiapkan siswa untuk pembelajaran dan menyampaikan materi yang akan dipelajari. Penanaman karakter dalam kegiatan ini melalui prilaku guru yang datang tepat waktu, memberikan salam dan menegur dengan sopan psiswa yang datang terlambat. (2) Kegiatan Inti. Kegiatan inti berisi tentang penyampaian materi pembelajaran dengan menggunkan pendekatan pemecahan masalah matematika dengan melaksanakan sesuai dengan tahap tahapnya. Penanaman nilai karakter dalam kegiatan ini dapat melalaui proses pembelajaran dengan memberikan motivasi, melatih keberanian, kegigihan dan kegiatan berdiskusi dengan sesama siswa atau guru.(3) Kegiatan Penutup. Kegiatan Penutup ini berisi tentang guru dan siswa bersama - sama menyimpulkan materi yang telah dibahas dan melakukan refleksi terhadap proses pembelajaran. Penanaman nilai karakter pada kegiatan ini adalah dengan saling menghargai dan percaya diri.

Berikut ini adalah Tabel penanaman pendidikan karakter dalam pembelajaran dengan pendekatan pemechan masalah matematika.

Tabel 1. Pemecahan Masalah dan Pendidikan Karekter

\begin{tabular}{l|l}
\hline \multicolumn{1}{c|}{ Tahap Pemecahan Masalah } & \multicolumn{1}{c}{ Nilai Pendidikan Karakter } \\
\hline $\begin{array}{l}\text { Memahami Masalah } \\
\text { ditanyakan dan informasi lain. }\end{array}$ & $\begin{array}{l}\text { Ketertarikan dan minat yang kuat dalam } \\
\text { memahami permasalahan }\end{array}$ \\
\hline $\begin{array}{l}\text { Membuat Perencanaan } \\
\text { Memformulasikan permasalahan dalm bentuk } \\
\text { model matematika. }\end{array}$ & $\begin{array}{l}\text { Keyakinan, keberanian diri dalam membuat } \\
\text { perencanaan }\end{array}$ \\
\hline $\begin{array}{l}\text { Melaksanakan Rencana Pemecahan Masalah } \\
\text { Menerapkan startegi pemecahan masalah } \\
\text { yang telah dibuat. }\end{array}$ & $\begin{array}{l}\text { Kerja keras, kemandirian, kegigihan dalam } \\
\text { melaksanakan rencana penyelesaian }\end{array}$ \\
$\begin{array}{l}\text { Mengecek Kembali } \\
\begin{array}{l}\text { Menjelaskan hasil yang diperoleh dengan } \\
\text { mengaitkan dengan permasalahan awal }\end{array}\end{array}$ & $\begin{array}{l}\text { Interaksi, negoisasi dalam memperoleh hasil } \\
\text { penyelesaian. }\end{array}$ \\
\hline
\end{tabular}




\section{SIMPULAN}

Berdasarkan pembahahasan di atas, maka diperoleh beberapa kesimpulan antara lain: (1) Penanaman pendidikan karakter tidak hanya menjadi kewajiban guru mata pelajaran Pendidikan Agama atau Pendidikan Pancasila, tetapi merupakan kewajiban setiap guru. (2) Pendidikan karakter meliputi penanaman nilai - nilai moral, etika, tingkah laku dan ucapan. (3) Penanaman pendidikan karater oleh guru dapat dilakukan dalam proses pembelajaran mulai dari awal kegiatan pembelajaran sampai kegiatan evaluasi. (4) Guru dapat menerapkan model model pembelajaran dalam rangka penanaman pendidikan karakter. Salah satunya adalah dengan pendekatan pemecahan masalah. Proses pemecahan masalah yang memerlukan beberapa tahap penyelesaian didalamnya, akan memuat beberapa nilai karakter, diantaraya kegigihan, minat dan kerjasama. 


\section{DAFTAR RUJUKAN}

Kesumawati, N. (2014). Kreativitas Berpikir Matematis Dalam Pembelajaran Berkarakter. DeltaPi: Jurnal Matematika Dan Pendidikan Matematika, 3(1), 110.

Liljedahl, P., Santos-Trigo, M., Malaspina, U., \& Bruder, R. (2016). Problem Solving in Mathematics Education. https://doi.org/10.1007/978-3-31940730-2

Maunah, B. (2016). Implementasi Pendidikan Karakter Dalam Pembentukan Kepribadian Holistik Siswa. Jurnal Pendidikan Karakter, 1, 90-101. https://doi.org/10.21831/jpk.v0i1.8 615

Novianti, D. E. (2017). Profil Pemecahan Masalah Matematika Dalam Menyelesaikan Permasalahan Pemrograman Linear Ditinjau Dari Kemampuan Komunikasi Matematis Mahasiswa. JIPM (Jurnal Ilmiah Pendidikan Matematika), 6(1), 53. https://doi.org/10.25273/jipm.v6i1. 1698

Novianti, D. E. (2019). How the Student's Error in Solution of Mathematics Problems? JIPM (Jurnal Ilmiah Pendidikan Matematika), $8(1), \quad 19$. https://doi.org/10.25273/jipm.v8i1. 4163

Omeri, N. (2015). Pentingnya pendidikan karakter dalam dunia pendidikan. Manager Pendidikan, 9(3).

Pambudi, D. S., Budayasa, I. K., \& Lukito, A. (2020). The Role of Mathematical Connections in Mathematical Problem Solving. Jurnal Pendidikan Matematika, 14(2), 129-144. https://doi.org/10.22342/jpm.14.2.
10985.129-144

Pendidikan, B. S. N. (2006). Standar Isi. Jakarta : BSNP.

Pertiwi, I., \& Marsigit, M. (2017). Implementasi pendidikan karakter dalam pembelajaran matematika SMP di Kota Yogyakarta. Jurnal Riset Pendidikan Matematika, 4(2), 153. https://doi.org/10.21831/jrpm.v4i2. 11241

Polya, G. (1973). How to Solve It. In Discovering Computer Science. Princeton University Press. https://doi.org/10.1201/978100303 7149-1

Suriyah, P., Waluya, S. ., \& Rochmad. (2020). Graph Theory As A Tool For Growing Mathematical Creativity. JPE ( Jurnal Pendidikan Edutama) Vol . 7 No . 1 Januari 2020, 7(1), 127-142.

Tambunan, H. (2019). The Effectiveness of the Problem Solving Strategy and the Scientific Approach to Students' Mathematical Capabilities in High Order Thinking Skills. International Electronic Journal of Mathematics Education, 14(2), 293-302. https://doi.org/10.29333/iejme/571 5 
124 JURNAL PENDIDIKAN EDUTAMA, Vol. 8, No.2 Juli 2021 